\title{
Mouse Tumor Necrosis Using Photodynamic Therapy
}

\author{
Necla Kenar ${ }^{1}$ and Hyun Soo Lim²,3* \\ ${ }^{1}$ Department of Physics, Science and Arts Faculty, Kocaeli University, Turkey \\ ${ }^{2}$ Department of Electrical and Electronics Engineering, Sakarya University, Turkey \\ ${ }^{3}$ Department of Biomedical Engineering, Chungnam National University, Korea
}

Submission: March 08, 2017; Published: March 31, 2017

*Corresponding author: Hyun Soo Lim, Department of Electrical and Electronics Engineering, Sakarya University, Esentepe Campus 54187 Serdivan/Sakarya, Turkey, Tel: 0 (264) 295 7204; Email: hyunlim@sakarya.edu.tr

\begin{abstract}
Background and aims: To investigate the efficacy of $630 \mathrm{~nm}$ and $650 \mathrm{~nm}$ light sources and compare to both light source for photodynamic therapy effects after treatment.

Material and methods: In the experimental method, we divided the mice into two control and test group which HepG2 and HeLa cell line induced cancer mass in mice. Photofrin was administered to the tumor-bearing mouse, followed 30 hours later by $630 \mathrm{~nm}$ and $650 \mathrm{~nm}$ laser light exposure. After photodynamic therapy, we analyzed the two mice group for the tumor mass size, tumor growth, tumor cell necrosis, pathological anatomy change.
\end{abstract}

Results: Experimental results show that tumor cell necrosis was shown in the tissue which the reduced size of tumor and tumor cell necrotic change according to the irradiation time and light dose amount.

Conclusion: The considerable difference, however, between the $630 \mathrm{~nm}$ and $650 \mathrm{~nm}$ wavelengths was not found for the tumor cell necrotic change and other damage of normal tissue was not found.

Keywords: Photodynamic Therapy; Tumor growth; Necrosis; Irradiation Time; Light dose 630nm and 650nm light sources

\section{Introduction}

Photodynamic therapy works through the combination of light absorbing compounds and activating light, one of the major challenges of cancer therapy is to preferentially destroy malignant cells while limiting systemic toxicity and sparing the normal tissue. Photodynamic therapy (PDT) employs drugs that localize to malignant tumors, as well as to certain other tissues. These drugs show no general toxicity and are only cytotoxic upon activation with specific wavelengths of light. The proper selection of drug (photosensitizers), interval between drug injection, and photo activation (pharmacokinetics/pharmacodynamics), drug dose, light dose, light-dose rate and field of illumination can result in good antitumor efficacy and selectivity. PDT light absorbing molecules (photo sensitizers) become cyto toxic upon illumination, but are relatively innocuous in the absence of light. Upon illumination the photo sensitizers undergo oxygen dependent photochemical reactions which lead to cyto toxicity at the site of photo sensitizer localization and illumination. Selectively is obtained by a moderates therapeutic ratio of photo sensitizer localization between tumor and normal tissue and by light treatment targeted preferentially to the tumor. The present study conducted to evaluate the efficacy of $630 \mathrm{~nm}$ and $650 \mathrm{~nm}$ light source and compared to both light source for photodynamic therapy effects for the before and after of treatment. Statistical analysis of the rate of tumor response, histological change, according to the amount of light and irradiation time was performed. Result has shown that both light source did produce a greater rate of tumor response after PDT. Histological and molecular analysis of the mice tumor demonstrated that similar results were obtained when both the $630 \mathrm{~nm}$ and $650 \mathrm{~nm}$ semiconductor laser were used as activating light sources.

\section{Material and Methods}

\section{Instrumentation of PDT laser}

A block diagram of developed portable PDT laser system is presented in (Figure 1). We have developed a sufficiently precise and reliable technique. Controlled high power radiation of a laser system can be employed for a photodynamic therapy of abdominal cavity, intra-tissue and surface tumor. (Figure 2) shows the developed PDT laser system. This system is equipped with a set of fiber-optic catheters for difference localizations, 
including lungs, stomach, bladder, mammary glard etc. The radiation method employed in this system is CW, Pulse and Burst Pulse for optical for PDT. The maximum radiation power achieved at the output of the optical unit of the laser system is $2 \mathrm{~W}$. The system allows the radiation power to be controlled are the required irradiation time to be set. The irradiation dose is calculated automatically. The system is base on a large service lifetime and compact.

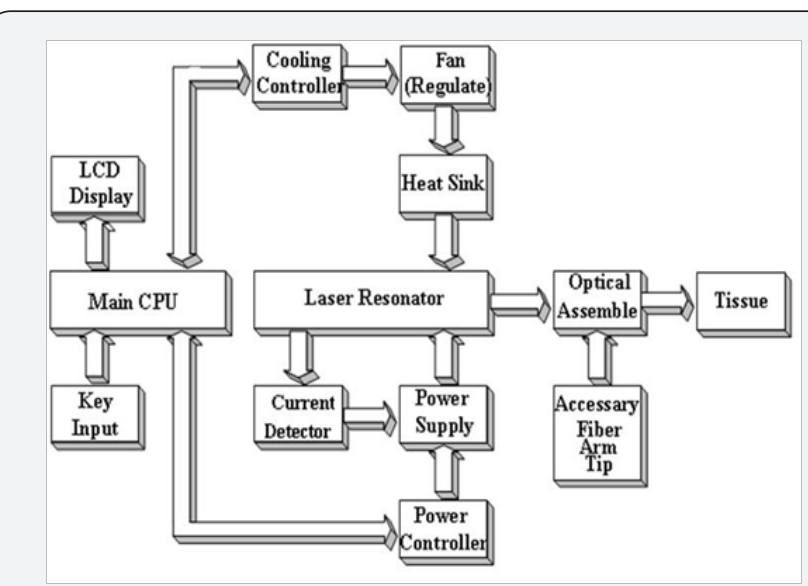

Figure 1: System block diagram.

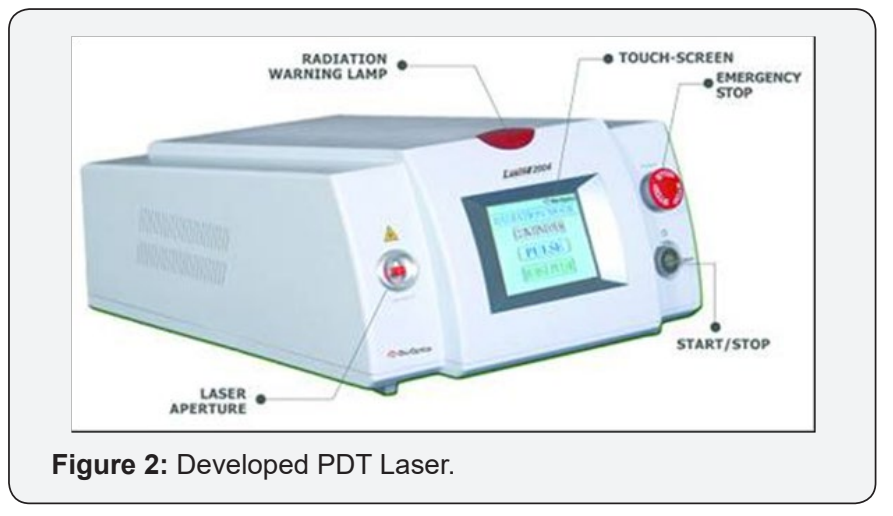

Table 2: HepG2 cell line (control group: $5 \%$ glucose injected).

\begin{tabular}{|c|c|c|c|c|c|c|c|c|c|}
\hline \multirow{3}{*}{$\begin{array}{c}\text { Wave length } \\
\begin{array}{c}\text { Irradiation } \\
\text { time }\end{array}\end{array}$} & \multirow{4}{*}{$\begin{array}{c}\text { Before } \\
\text { Treatment }\end{array}$} & \multicolumn{8}{|c|}{ After treatment } \\
\hline & & \multicolumn{4}{|c|}{$630 \mathrm{~nm}$} & \multicolumn{4}{|c|}{$650 \mathrm{~nm}$} \\
\hline & & \multicolumn{2}{|c|}{$5 \mathrm{~min}$} & \multicolumn{2}{|c|}{$10 \mathrm{~min}$} & \multicolumn{2}{|c|}{$5 \mathrm{~min}$} & \multicolumn{2}{|c|}{$10 \mathrm{~min}$} \\
\hline Light dose & & $20 \mathrm{~mW}$ & $40 \mathrm{~mW}$ & $20 \mathrm{~mW}$ & $40 \mathrm{~mW}$ & $20 \mathrm{~mW}$ & $40 \mathrm{~mW}$ & $20 \mathrm{~mW}$ & $40 \mathrm{~mW}$ \\
\hline Tumor size & $1.6 \times 1.2 \mathrm{~cm}$ & $2.2 \times 1.8$ & $2.3 \times 2.2$ & $2.3 \times 2.4$ & $1.9 \times 2.5$ & $2.2 \times 2.3$ & $1.9 \times 2.7$ & $2.4 \times 1.9$ & $2.1 \times 2.3$ \\
\hline $\begin{array}{l}\text { Tumor } \\
\text { growth rate }\end{array}$ & & $206.3 \%$ & $263.5 \%$ & $287.5 \%$ & $247.4 \%$ & $263.5 \%$ & $267.2 \%$ & $237.5 \%$ & $251.6 \%$ \\
\hline Tumor mass & $1.92 \mathrm{~cm}^{2}$ & 3.96 & 5.06 & 5.52 & 4.75 & 5.06 & 5.13 & 4.56 & 4.83 \\
\hline
\end{tabular}

The procedure of experimentation is shown in (Figure 3). We divided the mice into two control and test group which the Hep G2 and Hela cell line induced cancer mass in mice and applied the $630 \mathrm{~nm}$ and $650 \mathrm{~nm}$ laser system after 30 hours of injection of photo frin into the mice. After photodynamic therapy we analyzed the two mice group for the tumor mass size, tumor growth, tumor cell necrosis, pathological anatomy change.

\section{Results}

Table 1: Absorption coefficient comparison between normal tissue and tumor tissue according to two optical wavelengths.

\begin{tabular}{|c|c|c|}
\hline & $\mathbf{6 3 0 n m}$ & $\mathbf{6 5 0 n m}$ \\
\hline Muscle & 0.79508 & 0.80115 \\
\hline Fat & 0.73252 & 0.64500 \\
\hline Brain & 0.64494 & 0.59060 \\
\hline Tumor & 1.17047 & 1.31762 \\
\hline
\end{tabular}

(Table 1) shows the absorption coefficient comparison between normal tissue and tumor according to wavelengths of $630 \mathrm{~nm}$ and $650 \mathrm{~nm}$ using the spectroscopy. There is a little value of coefficient for both wavelengths and a little difference of coefficient can be predicated the same effects of PDT which both wavelengths are $630 \mathrm{~nm}$ and $650 \mathrm{~nm}$ (Table 2-5).

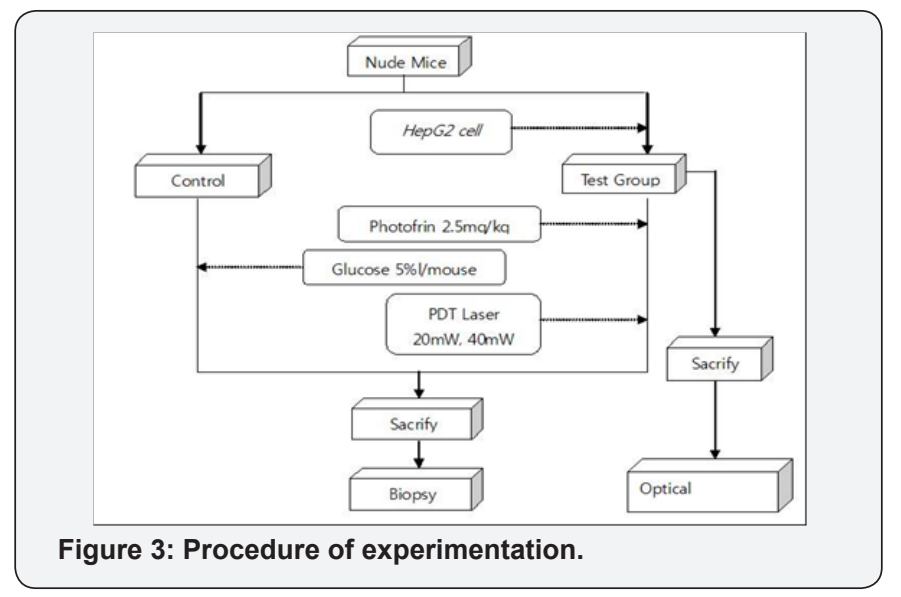




\section{Journal of Tumor Medicine \& Prevention}

Table 3: HepG2 cell line (test group: Photofrin $2.5 \mathrm{mg} / \mathrm{kg}$ ).

\begin{tabular}{|c|c|c|c|c|c|c|c|c|c|}
\hline & $\begin{array}{l}\text { Before } \\
\text { Treatment }\end{array}$ & \multicolumn{8}{|c|}{ After Treatment } \\
\hline Wave length & & \multicolumn{4}{|c|}{$630 \mathrm{~nm}$} & \multicolumn{4}{|c|}{$650 \mathrm{~nm}$} \\
\hline $\begin{array}{l}\text { Irradiation } \\
\text { time }\end{array}$ & & \multicolumn{2}{|c|}{$5 \mathrm{~min}$} & \multicolumn{2}{|c|}{$10 \mathrm{~min}$} & \multicolumn{2}{|c|}{$5 \mathrm{~min}$} & \multicolumn{2}{|c|}{$10 \mathrm{~min}$} \\
\hline Light dose & & $20 \mathrm{~mW}$ & $40 \mathrm{~mW}$ & $20 \mathrm{~mW}$ & $40 \mathrm{~mW}$ & $20 \mathrm{~mW}$ & $40 \mathrm{~mW}$ & $20 \mathrm{~mW}$ & $40 \mathrm{~mW}$ \\
\hline Tumor size & $1.5 \times 1.2 \mathrm{~cm}$ & $1.0 \times 1.1$ & $0.9 \times 0.8$ & $0.9 \times 0.9$ & $0.7 \times 0.5$ & $1.2 \times 0.9$ & $0.9 \times 0.8$ & $0.8 \times 1.0$ & $0.6 \times 0.6$ \\
\hline Necrosis & Non & 1.63 & 2.5 & 2.22 & 5.14 & 1.67 & 2.5 & 2.25 & 5 \\
\hline Tumor mass & $1.8 \mathrm{~cm}^{2}$ & 1.1 & 0.72 & 0.81 & 0.35 & 1.08 & 0.72 & 0.8 & 0.36 \\
\hline
\end{tabular}

Table 4: Hella cell line (control group: $5 \%$ glucose injected).

\begin{tabular}{|c|c|c|c|c|c|c|c|c|c|}
\hline \multirow{3}{*}{$\begin{array}{c}\text { Wave length } \\
\begin{array}{c}\text { Irradiation } \\
\text { time }\end{array}\end{array}$} & \multirow{4}{*}{$\begin{array}{c}\text { Before } \\
\text { Treatment }\end{array}$} & \multicolumn{8}{|c|}{ After Treatment } \\
\hline & & \multicolumn{4}{|c|}{$630 \mathrm{~nm}$} & \multicolumn{4}{|c|}{$650 \mathrm{~nm}$} \\
\hline & & \multicolumn{2}{|c|}{$5 \mathrm{~min}$} & \multicolumn{2}{|c|}{$10 \mathrm{~min}$} & \multicolumn{2}{|c|}{$5 \mathrm{~min}$} & \multicolumn{2}{|c|}{$10 \mathrm{~min}$} \\
\hline Light dose & & $20 \mathrm{~mW}$ & $40 \mathrm{~mW}$ & $20 \mathrm{~mW}$ & $40 \mathrm{~mW}$ & $20 \mathrm{~mW}$ & $40 \mathrm{~mW}$ & $20 \mathrm{~mW}$ & $40 \mathrm{~mW}$ \\
\hline Tumor size & $1.3 \times 1.5 \mathrm{~cm}$ & $2.2 \times 2.4$ & $2.1 \times 2.6$ & $2.7 \times 2.1$ & $2.2 \times 2.8$ & $2.9 \times 2.1$ & $2.4 \times 2.7$ & $2.1 \times 2.9$ & $2.7 \times 2.8$ \\
\hline $\begin{array}{l}\text { Tumor } \\
\text { growth rate }\end{array}$ & & $270.8 \%$ & $280.0 \%$ & $290.8 \%$ & $315.9 \%$ & $312.3 \%$ & $332.3 \%$ & $312.3 \%$ & $387.7 \%$ \\
\hline Tumor mass & $1.95 \mathrm{~cm} 2$ & 5.28 & 5.46 & 5.67 & 6.16 & 6.09 & 6.48 & 6.09 & 7.56 \\
\hline
\end{tabular}

Table 5: Hella cell line (test group: Photofrin $2.5 \mathrm{mg} / \mathrm{kg}$ ).

\begin{tabular}{|c|c|c|c|c|c|c|c|c|c|}
\hline & $\begin{array}{c}\text { Before } \\
\text { Treatment }\end{array}$ & \multicolumn{8}{|c|}{ After Treatment } \\
\hline Wave length & & \multicolumn{4}{|c|}{$630 \mathrm{~nm}$} & \multicolumn{4}{|c|}{$650 \mathrm{~nm}$} \\
\hline $\begin{array}{l}\text { Irradiation } \\
\text { time }\end{array}$ & & \multicolumn{2}{|c|}{$5 \mathrm{~min}$} & \multicolumn{2}{|c|}{$10 \mathrm{~min}$} & \multicolumn{2}{|c|}{$5 \mathrm{~min}$} & \multicolumn{2}{|c|}{$10 \mathrm{~min}$} \\
\hline Light dose & & $20 \mathrm{~mW}$ & $40 \mathrm{~mW}$ & $20 \mathrm{~mW}$ & $40 \mathrm{~mW}$ & $20 \mathrm{~mW}$ & $40 \mathrm{~mW}$ & $20 \mathrm{~mW}$ & $40 \mathrm{~mW}$ \\
\hline Tumor size & $1.4 \times 1.3 \mathrm{~cm}$ & $1.1 \times 0.9$ & $0.9 \times 0.9$ & $0.9 \times 0.8$ & $0.7 \times 0.6$ & $1.2 \times 0.8$ & $0.9 \times 0.8$ & $0.8 \times 1.0$ & $0.5 \times 0.8$ \\
\hline Necrosis & Non & 1.83 & 2.24 & 2.52 & 4.33 & 1.69 & 2.52 & 2.72 & 4.55 \\
\hline Tumor mass & $1.82 \mathrm{~cm} 2$ & 0.99 & 0.81 & 0.72 & 0.42 & 1.08 & 0.72 & 0.8 & 0.40 \\
\hline
\end{tabular}

After one week for injection of cancer cell line, it begins to observe the tumor growth and we found the tumor mass mice after 2 weeks. There is no mice of death or abnormal after an intravenous injection of drug and the drugs show no general toxicity for the mice group. In every ease photo sensitizer (drug) was injected intravenously 30 hours before applied irradiation of laser for the $630 \mathrm{nmand} 650 \mathrm{~nm}$ each $20 \mathrm{~mW}$ and $40 \mathrm{~mW}$ during 5 minutes and 10 minutes (Figure 4-11). After treatment of PDT, tumor necrosis and the reduced size mass was observed.

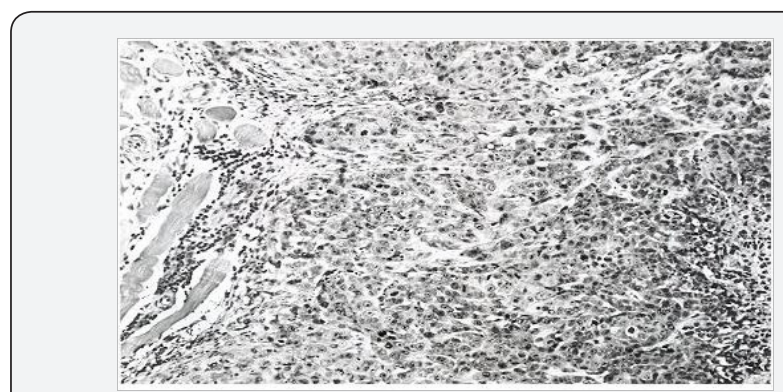

Figure 4: Cancer cell nests (implantation by HepG2 cell) infiltrating into the muscle bundles (H\&E 200X).

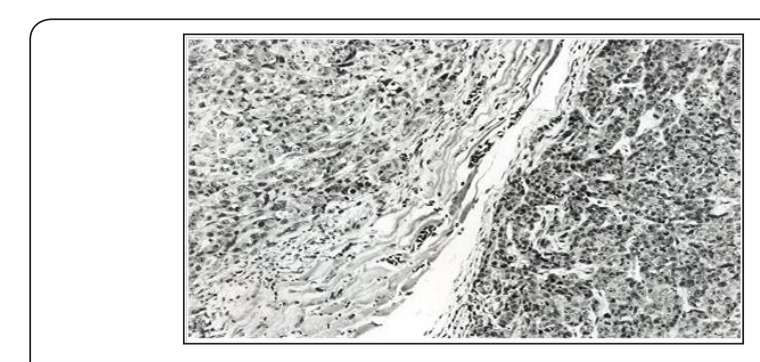

Figure 5: Cancer cell nests (implantion by HeLa cell) infiltrating into muscle byndles (H\&E 200X).

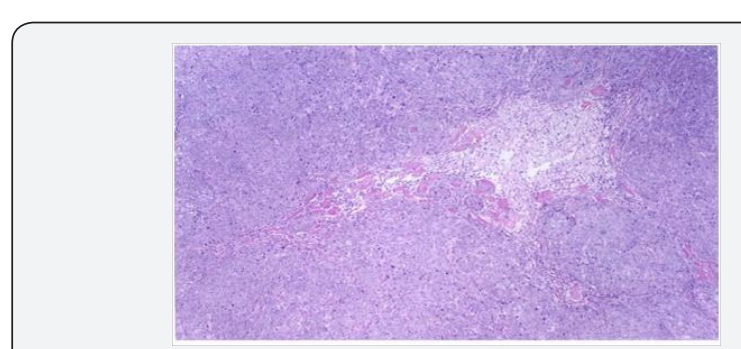

Figure 6: Tumor tissue shows necrotic change after PDT (H\&E 200x) $630 \mathrm{~nm}$, 20mW 5minutes. 


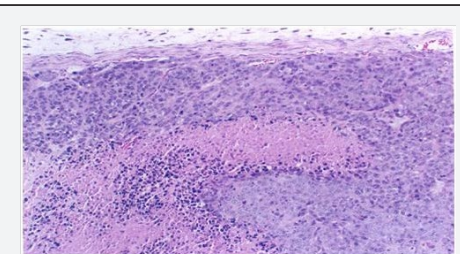

Figure 7: Tumor tissue shows necrotic change after PDT (H\&E 200X) $630 \mathrm{~nm}, 20 \mathrm{mw}, 10$ minutes.

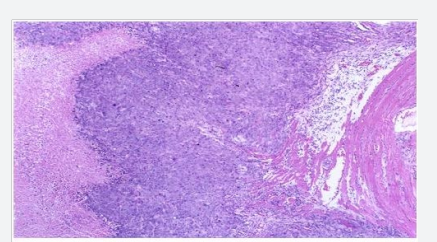

Figure 8: Tumor tissue shows necrotic change after PDT (H\&E 200X) $630 \mathrm{~nm}, 40 \mathrm{~mW}$, 5 minutes.

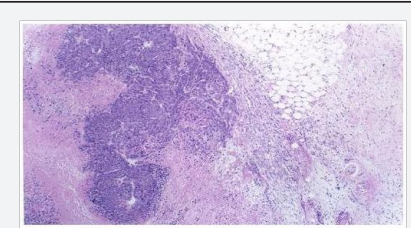

Figure 9: Tumor tissue shows necrotic change after PDT (H\&E 200X) 630nm, 40mW, 10minutes.

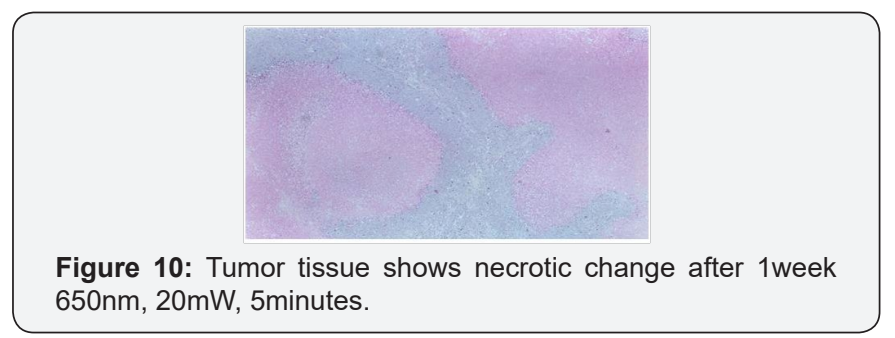

Figure 10: Tumor tissue shows necrotic change after 1 week $650 \mathrm{~nm}, 20 \mathrm{~mW}, 5$ minutes.

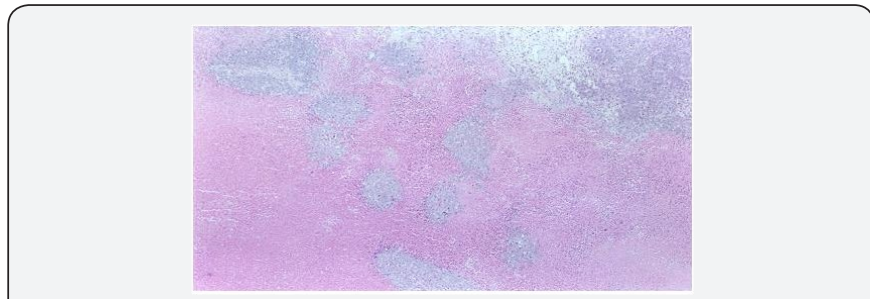

Figure 11: Tumor tissue shows necrotic change after 1 week $650 \mathrm{~nm}, 40 \mathrm{~mW}, 5$ minutes.

\section{Discussion}

We have performed the photodynamic therapy for the two mice group and analyzed the tumor mass size, tumor growth, tumor cell necrosis, pathological anatomy change. Experimental results show that tumor cell necrosis was shown in the tissue which the reduced size of tumor and tumor cell necrotic change according to the irradiation time and light dose amount. The considerable difference, however, between the $630 \mathrm{~nm}$ and $650 \mathrm{~nm}$ wavelengths was not found for the tumor cell necrotic change and other damage of normal tissue was not found.

\section{References}

1. Dougherty TJ, Gomer CJ, Henderson BW, Jori G, Kessel D, et al. (1998) Photodynamic therapy. J Natl Cancer Inst 90(12): 889-905.

2. Ruebner A, Kirsch D, Andress S, Decker W, Roeder B, et al. (1997) Dimeric Cyclodextrin Carriers with High Binding Affinity to Porphyrinoid Photosensitizers J Inclusion Phenom 27(1): 69-84.

3. Moser JG, Ruebner A, Vervoorts A, Wagner B (1996) In Proceedings of the Eighth International Symposium on Cyclodextrins. (ed.) Szetli J, Kulwer, Boston, USA. p. 71-76.

4. Kubler AC, Haase T, Staff C, Kahle B, Rheinwald M, et al. (1999) Photodynamic therapy of primary nonmelanomatous skin tumours of the head and neck. Lasers Surg Med 25(1): 60-68.

5. Lim HS (2003) The Development of $635 \mathrm{~nm}$ Diode Laser System for the Photodynamic Therapy of Cancer. Journal of the Korea Society of medical and Biological Engineering 24(4).

\begin{tabular}{l} 
Your next submission with Juniper Publishers \\
will reach you the below assets \\
- Quality Editorial service \\
- Swift Peer Review \\
- Reprints availability \\
- E-prints Service \\
- Manuscript Podcast for convenient understanding \\
- Global attainment for your research \\
- Manuscript accessibility in different formats \\
( Pdf, E-pub, Full Text, Audio) \\
- Unceasing customer service \\
Track the below URL for one-step submission \\
https://juniperpublishers.com/online-submission.php \\
\hline
\end{tabular}

